\title{
自己格子間原子と空孔の相互消滅反応方程式の検証
}

\author{
網 野 岳 文*1 荒 河一渡*2 森 博太郎 \\ 大阪大学超高圧電子顕微鏡センター \\ J. Japan Inst. Metals, Vol. 75, No. 8 (2011), pp. 460-464 \\ (C) 2011 The Japan Institute of Metals

\section{Verification of Rate Equation for Recombination between Self-Interstitial Atoms and Vacancies}

Takafumi Amino*1, Kazuto Arakawa*2 and Hirotaro Mori

Research Center for Ultra-High Voltage Electron Microscopy, Osaka University, Ibaraki 567-0047

Rate equation (RE) and kinetic Monte Carlo (KMC) simulation are widely used to understand the accumulation process of lattice defects upon high-energy particle irradiation. $\mathrm{RE}$ is more suitable for the simulation of longer term processes in comparison with KMC simulation. However, the accuracy of the results obtained by RE has not yet been clearly established. In the present study, the accuracy of RE for the reaction between self-interstitial atoms and vacancies in a body-centered cubic lattice is verified using a KMC method. The results show that the accuracy of RE reduces when the spatial correlation among defects is not negligible.

(Received April 11, 2011; Accepted May 16, 2011)

Keywords: crowdion, kinetic Monte Carlo simulation, reaction rate theory, self-interstitial atom, vacancy

\section{1. 緒言}

結晶を高エネルギー粒子で照射すると，一般には自己格子 間原子 (self-interstitial atom: SIA) と原子空孔 (vacancy: V) が同数導入される1).これらの点欠陥は結晶中を移動し, 異 種の欠陷同士が会合すると相互消滅を起こし，また，同種の 欠陥同士が会合すると結合して転位ループやボイドなどの点 欠陥集合体を形成する．これらの欠陥反応による欠陥の蓄積 は，照射された材料のサイズ变化や機械的特性の劣化の主な 要因である1). それゆえ, 点欠陷蓄積過程の理解は, 原子炉 や核融合炉などの高エネルギー粒子照射下で使用される材料 の寿命予測と新規材料開発の上で極めて重要である.

欠陷蓄積過程の理解のために, これまでに kinetic Monte Carlo (KMC) シミュレーションや, 欠陥反応速度論に基づ くコンピューターシミュレーションが開発され広く用いられ ている.これらの方法では, 個々のタイプの欠陥のデータを 入力パラメーターとして用い, 膨大な数の欠陥からなる欠陥 蓄積過程がシミュレートされる.

$\mathrm{KMC}$ シミュレーションでは, 個々の欠陥のふるまいが確

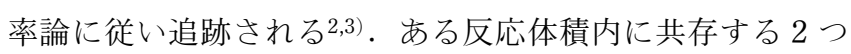
の欠陥はただちに反応する (反応体積は通常, ある反応半径 を持つ球体で近似される). $\mathrm{KMC}$ では, 個々の欠陷種の移 動頻度や欠陥同士の反応半径などの入力パラメーターが正し ければ得られる計算結果の定量性は優れていると考えられ

\footnotetext{
*1 大阪大学大学院生 (Graduate Student, Osaka University)

*2 独科学技術振興機構, 戦略的創造研究推進事業 (CREST, JST)
}

る.しかし，アルゴリズムの並列化が困難であり，このため 炉材料の寿命に匹敵する数十年のオーダーにわたる欠陥蓄積 過程の模擬は困難である.

一方, 欠陥反応速度論は, 大きく分けて, Frank, Seeger と Schottky ${ }^{4}$, Gösele と Frank ${ }^{5)}$ ， および Gösele と Seeger6) によって開発された欠陷同士の空間的相関の効果を取り入れ た拡散理論, ならびに, Frank ${ }^{7)}$, および Gösele と Frank ${ }^{5)}$ によって開発された平均場近似に基づく反応方程式の 2 つ に分類される. このうち拡散理論は, その式が比較的複雑で あるため, 極めて単純な反応にのみ適用され得る. 他方, 反 応方程式では, 個々のタイプの欠陥の濃度の時間微分がそれ ぞれの欠陷種の濃度および拡散係数(あるいはジャンプ頻度) の比較的簡単な関数として記述される. このため, 反応方程 式は, $\mathrm{KMC} に$ 比べ計算時間が短く済み, より長時間にわた る欠陷蓄積過程のシミュレーションに広く適用されている. しかし, 反応方程式による欠陷蓄積過程のシミュレーション 結果が定量的にどれほど信頼できるものか必ずしも明らかで はない.

照射下での欠陥の蓄積における最も基本的な要素過程は, $\mathrm{SIA}$ と SIA, V と V, および SIA と V の 3 種類の点欠陥同 土の反応である. 金属中の SIA の移動は, SIAの構造と結 びついた移動様式および移動頻度によって特徵づけられる. たとえば，体心立方 (BCC) 金属および面心立方 $(\mathrm{FCC})$ 金属 に颃いて, 候補となる複数の SIA の構造のうち, もっとも 可能性が高いと考えられる候補は，3 次元 $(3 \mathrm{D})$ 移動をする dumbbell, およびその最密軸に沿って 1 次元 (1D) 移動をす る crowdionの二つである ${ }^{8,9)}$. 拡散理論および反応方程式に 
おいて，移動するSIA と静止した欠陥との反応速度が定式 化され，この SIA の移動の次元 (3D または 1D) が反応速度 に大きな影響を与えるファクターであることが示されてい $ろ^{5-7,10,11)}$.

我々は，BCC 格子に拈る SIA-SIA の反応過程を $\mathrm{KMC}$ によって解析し, 得られた結果に基づいて SIA-SIA 反応方 程式の次数を移動次元が $3 \mathrm{D}$ および $1 \mathrm{D} の$ 場合について求め ている12)。 また, 複数の SIA のみを含む系のアニーリング 過程を KMCによって解析し, 反応方程式による解析の定量 性を検証している. その結果, 平均場近似に基づいて立式さ れた SIA-SIA 反応方程式の結果は半定量的には KMC シミ ュレーション結果と一致すること, しかしアニーリング時間 が長くなると, SIA-SIA 間の空間分布が一様分布から外れ ていくために反応方程式によるシミュレーションの定量性が 悪くなることが明らかにされた12).

本研究では, BCC 格子における SIA と V の相互消滅反応 に着目し，KMCによる解析を行うとともにその結果に基づ いて反応方程式の定量性を評価する. SIA-V の反応方程式 は, 確率論によって既に導出がなされている5,7). しかし,

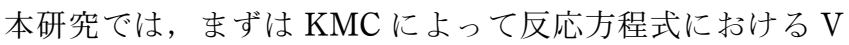

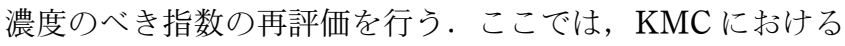
反応半径と反応方程式に打ける反応の幾何学的定数との関係 も明らかにする。次に，KMCにより SIA と V からなる系 のアニーリング過程を解析する. 得られた解析結果を反応方 程式の結果と比較して, 反応方程式の定量性を検証する.こ こでは併せて, 拡散理論式の結果との比較も行い, その定量 性を検証する。

\section{2. 方法}

\section{1 反応方程式の概要}

移動する SIA と静止したトラップとの反応方程式は, Frank $^{7)}$ ，および Gösele と Frank ${ }^{5)}$ によって最初に導出され た. その後，この反応方程式は膨大な数の系に適用されてい る1,11,13).ここでは, Barashev, Golubov と Trinkaus ${ }^{10)} に よ$ るレビューを参考にして反応方程式の立式の概要を説明す る. 本論文では，SIAのトラップとして V のみが存在する 系を考えることにする．

SIA の濃度 $C_{\mathrm{I}}$ の時間変化は次の式で与えられる.

$$
-\frac{1}{C_{\mathrm{I}}} \frac{d C_{\mathrm{I}}}{d t}=\frac{1}{\tau}
$$

ここで, $t$ は時間, $\tau$ は, SIA が 1 つのトラップに捕捉され るまでの平均時間，すなわち SIA の平均寿命である. $\tau$ は,

トラップの濃度と SIA のジャンプ頻度 $M_{\mathrm{I}}$ の関数で表すこと ができる．本論文では，各欠陥種の濃度を格子点数あたりの 欠陥の数(無次元量)で定義することとする.

SIA のトラップとして, 空間的に一様に分布した静止し た Vのみを考える，このとき， $\tau$ は確率論に基づいて次式で 与えられる.

3D:

$$
\tau_{\mathrm{IV}, 3 \mathrm{D}}=\frac{1}{Z_{\mathrm{IV}, 3 \mathrm{D}} M_{\mathrm{I}} C_{\mathrm{V}}^{\alpha_{\mathrm{IV}, 3 \mathrm{D}}}}\left(\alpha_{\mathrm{IV}, 3 \mathrm{D}}=1\right)
$$

1D:

$$
\tau_{\mathrm{IV}, 1 \mathrm{D}}=\frac{1}{Z_{\mathrm{IV}, 1 \mathrm{D}} M_{\mathrm{I}} C_{\mathrm{V}}^{\alpha_{\mathrm{V}, 1 \mathrm{D}}}}\left(\alpha_{\mathrm{IV}, 1 \mathrm{D}}=2\right)
$$

ここで, $Z$ は幾何学的定数, $C_{\mathrm{V}}$ は $\mathrm{V}$ の濃度, $\alpha$ はべき指数 定数である. 下付き文字の IV は SIA と V の反応を，3D お よび 1D はそれぞれ SIAの移動次元を表す。式(2)拈よび式 (3)に示されるように， $\tau$ のトラップ濃度への依存性は SIA の移動次元によって变わる.

式 (2) に打ける幾何学的定数 $Z_{\mathrm{IV}, 3 \mathrm{D}}$ の反応半径 $r_{\mathrm{IV}}$ に対す る関数関係は, 反応速度律速, 拡散律速およびそれらの混合 型の場合でそれぞれ表式が異なる. 連続体近似による理論式 は，それぞれの場合について次式で与えられる1). 反応速度律速 :

$$
Z_{\mathrm{IV}, 3 \mathrm{D}}=6 \pi r_{\mathrm{IV}}^{2}
$$

拡散律速 :

$$
Z_{\mathrm{IV}, 3 \mathrm{D}}=4 \sqrt{3} \pi r_{\mathrm{IV}}
$$

混合型：

$$
Z_{\mathrm{IV}, 3 \mathrm{D}}=12 \pi r_{\mathrm{IV}}^{2} /\left(2+\sqrt{3} r_{\mathrm{IV}}\right)
$$

ここで， $r_{\mathrm{IV}}$ は原子間距離を単位にとることとする.

一方，式(3)に抢ける幾何学的定数 $Z_{\mathrm{IV}, 1 \mathrm{D}}$ は，連続体近似に よって,

$$
Z_{\mathrm{IV}, 1 \mathrm{D}}=\frac{27}{8}\left(\pi r_{\mathrm{IV}}^{2}\right)^{2}
$$

で与えられる10). 本研究では，式(2)抢よび式 (3)における べき指数定数 $\alpha_{\mathrm{IV}, 1 \mathrm{D}}$ および $\alpha_{\mathrm{IV}, 3 \mathrm{D}}$ を評価する. また，式 (4) 〜 (7)の妥当性について検証する. そのための KMCシミュ レーションの条件を次節に述べる.

\section{2 べき指数定数および幾何学的定数の KMC による評価}

空間的に一様に配置された複数の静止した V と 1 つの移 動する SIA を含む系を設定する．このSIA があるV と出会 うまでの時間(寿命)を， $C_{\mathrm{V}}, r_{\mathrm{IV}}$ の関数として求める.この 系では，すべての欠陥の空間分布の一様性はほぼ保たれる。 なお， 3.2 節で述べるように, 複数の $\mathrm{V}$ と複数の SIA が配 置されたより現実的な系を考えた場合，欠陥の空間分布の一 様性は保たれない。

$\mathrm{KMC}$ シミュレーションの条件は以下のと拈りである.

(1) シミュレーション・セルは, SIA の移動次元が 3D の 場合は, $200 \times 200 \times 200$ 単位 BCC 格子である. SIA の移動 次元が $1 \mathrm{D}$ の場合は，セルは，〈111〉方向に中心軸を持つ円 筒である. そのサイズは, 中心軸に沿って $10^{6}$ 格子点, 動径 方向には $r_{\mathrm{IV}}$ の半径を持つ。 また, SIA の移動次元が 3D の 場合は，すべての方向に周期境界条件を適用する. SIA の 移動次元が $1 \mathrm{D}$ の場合は, 中心軸の方向にのみ周期境界条件 を適用する。

(2) SIA 抢よび V は格子点に存在する. SIA の移動次元 が $1 \mathrm{D}$ の場合は，SIA は中心軸上にのみ存在し得る.

(3) $\mathrm{V}$ が初期配置される格子点は， $C_{\mathrm{V}}$ の值 (条件(6)参照) に応じた数だけ, 全格子点から等確率で選ばれる。この際, 同一の格子点に二つ以上の $\mathrm{V}$ が重複して存在しないという 条件が課される.

（4）SIAの移動は通常の object $\mathrm{KMC}^{2,3)}$ の手法に従っ 
て，確率的に起こる。即ち，連続する 2 移動の時間間隔の 分布は平均值 $1 / M_{\mathrm{I}}$ の指数分布に従う.ここでは， $M_{\mathrm{I}}=4.53$ $\times 10^{11} \mathrm{~s}^{-1}$ とした(この值の詳細は本研究では重要な意味は ない).

（5） SIA の移動方向は, SIA の移動次元が 3D の場合は, 8 つの 111$\rangle$ 方向のいずれかが等確率で選ばれる. SIAの移 動次元が 1Dの場合は, シミュレーション・セルの中心軸に 沿った 2 方向のいずれかが等確率で選ばれる。いずれの場 合も，1回の移動につき，1原子間距離だけ SIA は移動する.

(6) $C_{\mathrm{V}}$ の值は, $1 \times 10^{-5} \sim 1 \times 10^{-2}, r_{\mathrm{IV}}$ の值は, $1 \sim 8$ の 範囲で変化させる。

（7）それぞれの $C_{\mathrm{V}}, r_{\mathrm{IV}}$ の組み合わせに対して，Vの 1000 通りの初期配置について $(1) \sim(5)$ の条件の下で SIA の寿命を 求め，その平均をもって $\tau$ とする.

\subsection{SIA と V からなる系のアニーリング過程の解析}

2.2 節で採用する系は，欠陥どうしの空間分布の一様性を 保つために設定するものであり，現実的でない。複数の V と同数の SIA が存在する，より現実的な系のアニーリング を $\mathrm{KMC}$ によって行い，2.1 節の手法で求められる反応方程 式の定量性をチェックする。この比較的単純な系について は，拡散理論による反応速度の近似式が得られている。した がって，拡散理論の定量性についても共に検証する。

ここでの object-KMCの条件は次のとおりである.

(1) シミュレーション・セルは, SIA の移動次元が 3D の 場合は， $200 \times 200 \times 200$ 単位 BCC 格子，1D の場合は，290 $\times 290 \times 290$ 単位 BCC 格子とする．また，すべての方向に 周期境界条件を適用する。

(2) SIA および V は格子点に存在する.

(3) SIA および $\mathrm{V}$ が初期配置される格子点は， $C_{\mathrm{I}}$ と $C_{\mathrm{V}}$ の值 (条件(5)参照)に応じた数だけ, 全格子点から等確率で選 ばれる。この際，同一の格子点に二つ以上の SIA（あるいは V)が重複して存在しないという条件，抢よびすべての SIA$\mathrm{V}$ 対間の距離は， $r_{\mathrm{IV}}$ (条件(5)参照)より大きいという条件が 課される.

（4） SIAの移動の起こり方は，2.1 節と同様とする．ただ し，SIA の移動次元が 1D の場合，それぞれのSIAの移動 軸は初めに 8 つ 〈111〉方向から等確率で選ばれる．その後 の移動方向は，初めに選ばれた移動軸に沿った 2 つの方向 のいずれかが等確率で選ばれる.

(5) $C_{\mathrm{I}}$ と $C_{\mathrm{V}}$ の初期値は， $1 \times 10^{-2}, r_{\mathrm{IV}}$ の值は 1 とする.

\section{3. 結 果·考 察}

\section{1 べき指数定数および幾何学的定数の KMC による評価}

Fig. 1 は，KMC によって得られた SIA の移動次元が 3D および $1 \mathrm{D}$ の場合についての $\tau$ の $C_{\mathrm{V}}$ に対する依存性を示 す。ここで， $r_{\mathrm{IV}}=1$ である. 平均寿命 $\tau_{\mathrm{IV}, 3 \mathrm{D}}$ と $\tau_{\mathrm{IV}, 1 \mathrm{D}}$ はそれ ぞれ $1 / C_{\mathrm{V}}^{\alpha_{\mathrm{IV}, 3 \mathrm{D}}}\left(\alpha_{\mathrm{IV}, 3 \mathrm{D}}=1.03 \pm 0.01\right)$ および $1 / C_{\mathrm{V}}^{\alpha_{\mathrm{V}, 1 \mathrm{D}}}\left(\alpha_{\mathrm{IV}, 1 \mathrm{D}}=\right.$ $1.98 \pm 0.03)$ にほぼ比例することがわかる。この結果は，既 存の理論式，式(2)抽び式(3)と合致する.

Fig. 2 に KMC で求めた $Z_{\mathrm{IV}, 3 \mathrm{D}}$ および $Z_{\mathrm{IV}, 1 \mathrm{D}}$ の $r_{\mathrm{IV}}$ 依存性

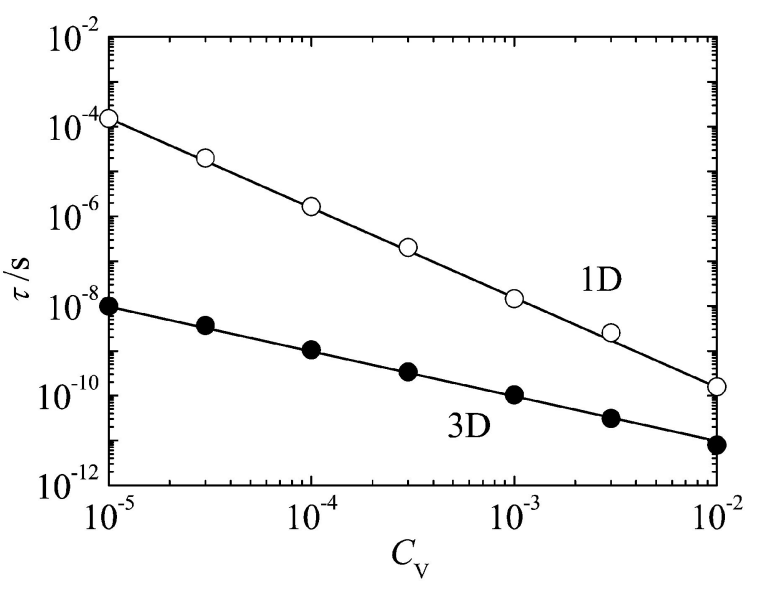

Fig. 1 Dependence of the average lifetime of one SIA, $\tau$, on the concentration of vacancies, $C_{\mathrm{V}}$, for the case of a $3 \mathrm{D}$ and $1 \mathrm{D}$ migrating SIA. (reaction radius, $r_{\mathrm{IV}}=1$ )

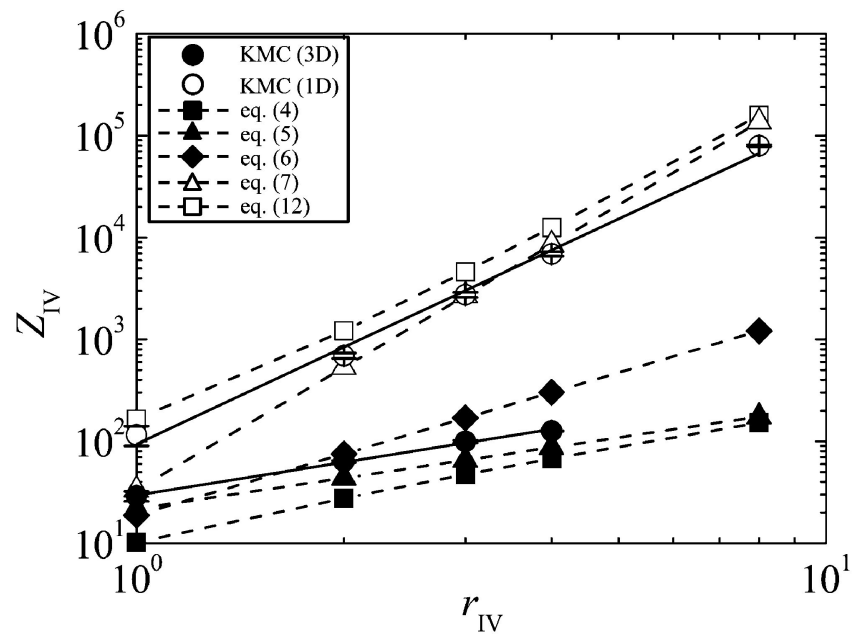

Fig. 2 Dependence of the geometrical constant for the reaction between an SIA and a vacancy, $Z_{\mathrm{IV}}$, on $r_{\mathrm{IV}}$, for a $3 \mathrm{D}$ and $1 \mathrm{D}$ migrating SIA.

をそれぞれ○印および○印にエラーバーをつけて示す。それ ぞれの $Z_{\mathrm{IV}, 3 \mathrm{D}}$ 抢よび $Z_{\mathrm{IV}, 1 \mathrm{D}}$ の $\gamma_{\mathrm{IV}}$ 依存性は $Z_{\mathrm{IV}, 3 \mathrm{D}}=(29.5 \pm$ 0.1) $r_{\mathrm{IV}}^{1.08 \pm 0.04}$ および $Z_{\mathrm{IV}, 1 \mathrm{D}}=(94.1 \pm 0.8) r_{\mathrm{IV}}^{3.16 \pm 0.13}$ で近似的に フィットされる，したがって， $\tau$ は次式で近似されることに なる。

$$
\begin{aligned}
\tau_{\mathrm{IV}, 3 \mathrm{D}} & =\frac{1}{30 r_{\mathrm{IV}}^{1.1} M_{\mathrm{I}} C_{\mathrm{I}}^{1}} \\
\tau_{\mathrm{IV}, 1 \mathrm{D}} & =\frac{1}{94 r_{\mathrm{IV}}^{3.2} M_{\mathrm{I}} C_{\mathrm{I}}^{2}}
\end{aligned}
$$

式（1）に式（８）扎よ゙式（9)を代入すると, SIAの移動次 元が $3 \mathrm{D}$ および $1 \mathrm{D}$ の場合の反応方程式として次式が得られ る.

$$
\begin{aligned}
& \left(-\frac{d C_{\mathrm{I}}}{d t}\right)_{\mathrm{IV}, 3 \mathrm{D}}=30 r_{\mathrm{IV}}^{1.1} M_{\mathrm{I}} C_{\mathrm{I}} C_{\mathrm{V}} \\
& \left(-\frac{d C_{\mathrm{I}}}{d t}\right)_{\mathrm{IV}, 1 \mathrm{D}}=94 r_{\mathrm{IV}}^{3.2} M_{\mathrm{I}} C_{\mathrm{I}} C_{\mathrm{V}}^{2}
\end{aligned}
$$

Fig. 2 には，式 $(4) \sim(7)$ で与えられた $Z_{\mathrm{IV}}=Z_{\mathrm{IV}}\left(r_{\mathrm{IV}}\right)$ の 理論式により得られる計算值を併せて示した. SIAの移動 
次元が $3 \mathrm{D}$ の場合, $\mathrm{KMC}$ で得られた $Z_{\mathrm{IV}, 3 \mathrm{D}}$ の $r_{\mathrm{IV}}$ 依存性と 最も近い理論式は，拡散律速反応の場合のもの(式（5))で ある.これに対して，SIAの移動次元が $1 \mathrm{D}$ の場合，KMC で得られた $Z_{\mathrm{IV}, 1 \mathrm{D}}$ と既存の連続体近似で求められた理論式 (式 $(7)$ ) との合致は良くない. 特に $r_{\mathrm{IV}}$ が小さい場合, その 偏倚は大きい。これは， $r_{\mathrm{IV}}$ が小さいときは，格子の影響が 顕著に効くためと考えられる．格子の影響を考慮に入れるた めに, 単純に, 式 $(7)$ 中の $\pi r_{\mathrm{IV}}^{2}$ をシリンダ一断面積中の格 子点数で置き換えると，新たに次式が得られる.

$$
Z_{\mathrm{IV}, 1 \mathrm{D}}=\frac{27}{8}\left(3 r_{\mathrm{IV}}^{2}+3 r_{\mathrm{IV}}+1\right)^{2}
$$

式(12)で与えられる $Z_{\mathrm{IV}, 1 \mathrm{D}}$ の值も, Fig. 2 中に示した. 式 ( 7 ) に格子の影響を取り入れることによって, $Z_{\mathrm{IV}, 1 \mathrm{D}}$ の $r_{\mathrm{IV}}$ に対する変化の形状は KMCの結果により近づくことがわか る。

\subsection{SIA と V からなる系のアニーリング}

Fig. 3 は, SIA の移動次元が 3D あるいは 1D の場合の, アニーリングによる $C_{\mathrm{I}}$ の時間依存性を示す．ここで， $r_{\mathrm{IV}}=$ 1 である. Fig. 4 は， $C_{\mathrm{I}}$ の時間微分の負值 $-d C_{\mathrm{I}}(t) / d t$ の $C_{\mathrm{I}}$ 依存性を示す. Fig. 3 および Fig. 4 中には, 3.1 節で KMC の結果を反映させて求めた式(10) および式(11)の反応方程 式の解も表示する. さらに, Gösele と Seeger6) によって半 解析的に導かれた拡散理論式の解も併せて示す.この拡散理

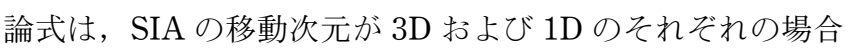
について次式で表すことができる.

$$
\begin{gathered}
\left(-\frac{d C_{\mathrm{I}}}{d t}\right)_{\mathrm{IV}, 3 \mathrm{D}}=\frac{C_{\mathrm{I}} C_{\mathrm{V}}}{\Omega} 4 \pi r_{\mathrm{IV}} D_{\mathrm{I}}\left[1+\frac{r_{\mathrm{IV}}}{\left(\pi D_{\mathrm{I}} t\right)^{1 / 2}}\right] \\
\left(-\frac{d C_{\mathrm{I}}}{d t}\right)_{\mathrm{IV}, 1 \mathrm{D}}=\frac{C_{\mathrm{I}} C_{\mathrm{V}}}{\Omega} 2 \pi r_{\mathrm{IV}}^{2}\left(\frac{D_{\mathrm{I}}}{\pi t}\right)^{1 / 2}
\end{gathered}
$$

ここで， $D_{\mathrm{I}}$ は SIA の拡散係数である. Fig. 3 および Fig. 4 からわかるように, 反応方程式の解は, SIA の移動の次元 に関わらず，KMCシミュレーションによる結果と定性的に は一致するが, 定量的には一致しない。このことは, 次に述 べるように反応方程式では欠陥どうしの空間相関の効果が取 り入れられていないためと考えられる. 一方, 拡散理論式の 解は, 長時間では, 反応方程式の解とほぼ一致することがわ かる. しかし短時間での解は, 拡散理論式が欠皕どうしの空 間相関をある程度考慮しているにも関わらず，KMCの結果 と定性的にも一致しない. これは, 式(13)に打ける右辺第 2 項(短時間項)の近似の度合いが悪いためであると考えられる.

Fig. 5 は，SIA 抢よび $\mathrm{V}$ が一様分布している系と，ア ニーリング後の系について， SIAのまわりのVの動径分布 関数を比較するものである.ここに，前者の系は， $C_{\mathrm{I}}$ 抢よ び $C_{\mathrm{V}}$ が $1 \times 10^{-3}$ の条件のもとで SIA および V が一様に配 置されたものである. 後者の系は $C_{\mathrm{I}}$ および $C_{\mathrm{V}}$ の初期值が 1 $\times 10^{-2}$ のもとで SIA 抢よび V が一様に配置された系を両濃 度が $1 \times 10^{-3}$ になるまでアニーリングしたものである．Fig. 5 より，アニーリングによって，SIAの付近の $C_{\mathrm{V}}$ の值が低 下することがわかる，この要因は，その間隔が平均距離より も短い SIA-V 対が優先的に衝突 · 反応することによって, 残される SIA-V 対間の距離が一様分布のそれに比べて長く

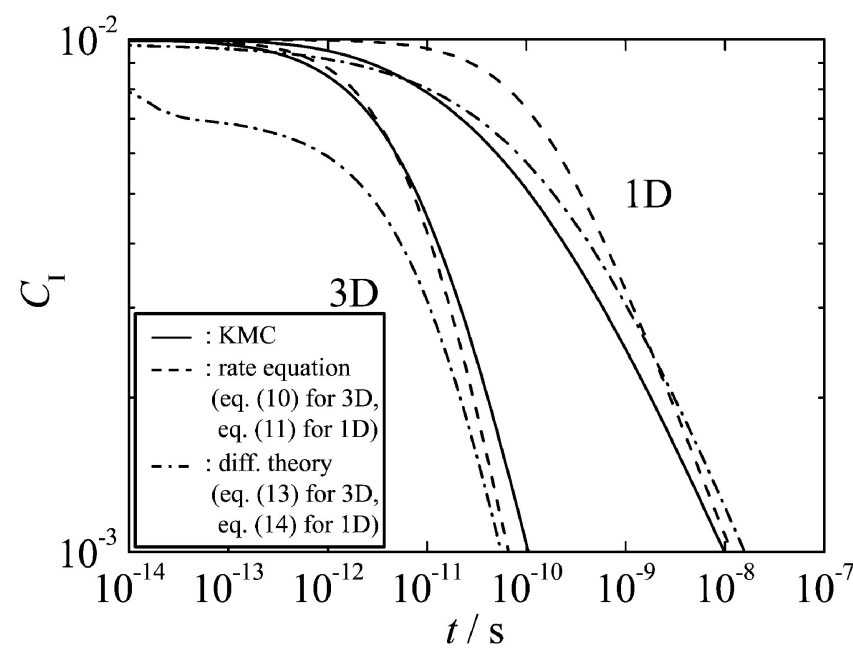

Fig. 3 Dependence of $C_{\mathrm{I}}$ on time, $t$, under annealing of systems composed of SIAs and vacancies. $\left(\gamma_{\mathrm{IV}}=1\right)$

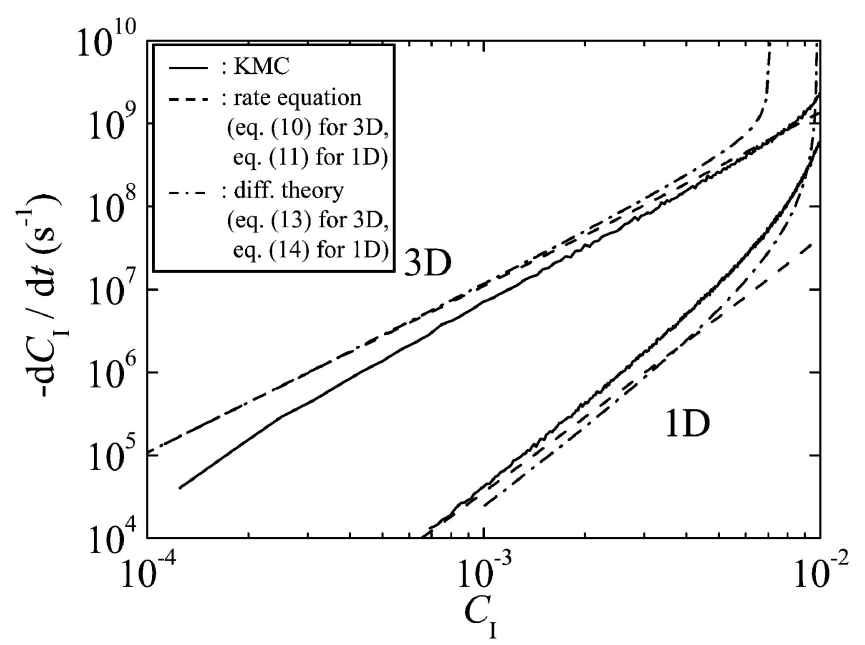

Fig. 4 Dependence of the negative temporal derivative of the SIA concentration, $-d C_{\mathrm{I}} / d t$, on $C_{\mathrm{I}}$, under annealing of systems composed of SIAs and vacancies. $\left(r_{\mathrm{IV}}=1\right)$

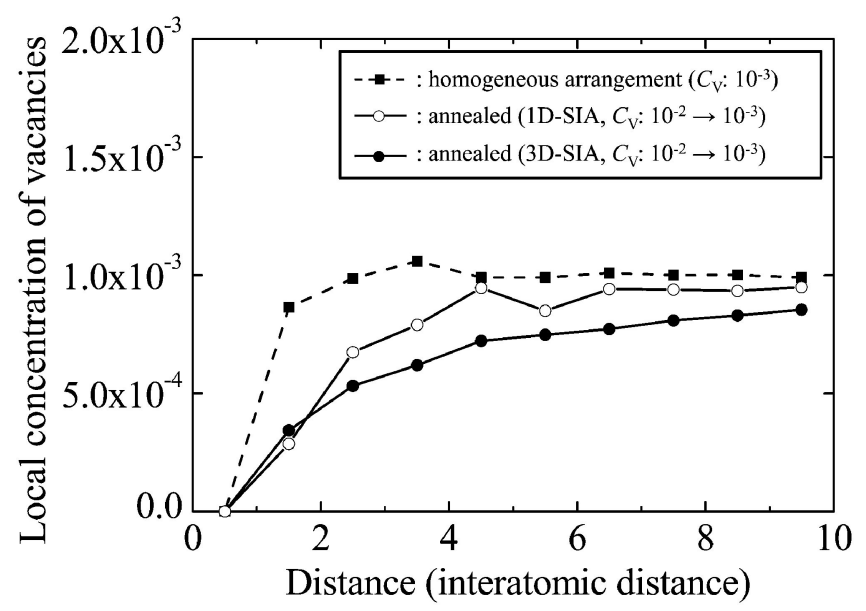

Fig. 5 Radial distribution function of vacancies around SIAs $\left(r_{\text {IV }}=1\right)$ after its conversion to the local concentration of vacancies. The results are shown for a system with a homogeneous arrangement of vacancies with $C_{\mathrm{v}}=1 \times 10^{-3}$, and for systems annealed from a state including homogeneously arranged SIAs with $C_{\mathrm{v}}=1 \times 10^{-2}$ to that with $C_{\mathrm{v}}=1 \times 10^{-3}$. 
なるためであると考えられる。この場合，アニーリング初期 には, 反応速度は反応方程式よりも高くなると期待される. この傾向は Fig. 4 に示される結果と合致する. 一方，ア ニーリング後期には, SIA のまわりの V の濃度が平均濃度 よりも低くなるため, 反応速度は反応方程式より短くなるは ずである.この傾向も Fig. 4 に示される結果と合致してい る.

\section{4. 結言}

本研究では, BCC 格子中の SIA と空孔の相互消滅反応に ついて，KMC 法を用いて調べ，次の知見を得た.

第 1 に, 複数の静止した $\mathrm{V}$ と 1 つの SIA からなる系に対 して, SIA の移動次元が 3D および $1 \mathrm{D}$ のそれぞれの場合に ついて，反応方程式に抢ける， $C_{\mathrm{V}}$ のべき指数を評価すると ともに， $Z_{\mathrm{IV}}$ の $r_{\mathrm{IV}}$ 依存性を求めた． $C_{\mathrm{V}}$ のべき指数は, SIA の移動次元によらず既存の理論と合致した。一方， $Z_{\mathrm{IV}}$ の $r_{\mathrm{IV}}$ 依存性は, $Z_{\mathrm{IV}, 3 \mathrm{D}}=30 r_{\mathrm{IV}}^{1.1}, Z_{\mathrm{IV}, 1 \mathrm{D}}=94 r_{\mathrm{IV}}^{3.2}$ となった。 $Z_{\mathrm{IV}, 1 \mathrm{D}}$ に関する既存の理論式およびその単純な改良版(式 (12))は，これらの結果と定量的には一致しなかった。これ は，これらの理論式には，格子の影響が十分に取り入れられ ていないためである. したがって, 結晶における幾何学的定 数の反応半径依存性を定量評価する場合には，ここで行った

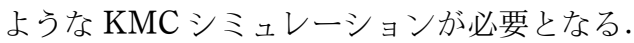

第 2 に, SIA と空孔が同濃度で配置された系のアニーリ ングを調べ，得られた結果を反応方程式および拡散理論式の 結果と比較した。 その結果, 本研究で得られた反応方程式の 結果は KMCの結果を定性的には再現したが定量的には $\mathrm{KMC}$ の結果と一致しなかった。一方，拡散理論式は，反応 方程式よりも再現性が悪かった. アニーリングの進行に伴っ て，SIAの周りのV の空間分布は一様分布からずれていっ た。このような欠陥の空間分布の非一様性が，反応方程式の 定量性を悪くする要因と考えられる。

本研究は, 照射下での欠陷蓄積過程やアニーリングによる
欠陥反応を反応方程式によって解析する際, 特に欠陥どうし の相関が問題になると考えられる，高照射量，あるいは長時 間アニーリングの条件では，その結果の解釈に注意が必要で あることを示す。したがって，照射によって導入された欠陥 の数密度やサイズ分布等の観察から, 久陥に関するパラメー ターを定量評価する場合，併用されるシミュレーション法と しては，KMC 法が第 1 選択肢となると考えられる. 現在, 超高圧電子顕微鏡による高エネルギー電子照射と KMC の組 久合わせによる欠陷パラメーターの定量的な評価の試みがよ うやくためされ始めているところである.

本研究は, 科学研究費補助金 (21560686 および 22224012), 研究拠点形成費補助金グローバル COE プログ ラム「構造・機能先進材料デザイン教育研究拠点」（大阪大 学), 日本鉄鋼協会鉄鋼研究振興助成, および公益財団法人 池谷科学技術振興財団の助成のもとに実施された.

\section{文献}

1) G. S. Was: Fundamentals of Radiation Materials Science: Metals and Alloys, (Springer-Verlag, Berlin, 2007).

2) N. Soneda and T. D. de la Rubia: Philos. Mag. A 81(2001) 331.

3) C. Domain, C. S. Becquart and L. Malerba: J. Nucl. Mater. 335 (2004) 121.

4) W. Frank, A. Seeger and G. Schottky: Phys. Status Solidi 8 (1965) 345.

5) U. Gösele and W. Frank: Phys. Status Solidi B 61(1974) 163.

6) U. Gösele and A. Seeger: Philos. Mag. 34(1976) 177.

7) W. Frank: Defects in Refractory Metals, ed. by R. D. Batist, J. Nihoul and L. Stals, (SCK/CEN, Mol, 1972) pp. 199-215.

8) J. W. Corbett: Electron Radiation Damage in Semiconductors and Metals, Solid State Phys., Supplement 7, ed. by F. Seitz and D. Turnbull, (Academic Press New York and London, 1966).

9) P. M. Derlet, D. Nguyen-Manh and S. L. Dudarev: Phys. Rev. B $\mathbf{7 6}(2007) 054107$.

10) A. V. Barashev, S. I. Golubov and H. Trinkaus: Philos. Mag. 81 (2001) 2515

11) B. N. Singh, S. I. Golubov, H. Trinkaus, A. Serra, Y. N. Osetsky and A. V. Barashev: J. Nucl. Mater, 251 (1997) 107.

12) T. Amino, K. Arakawa and H. Mori: Philos. Mag. 91(2011) 3276.

13) M. Kiritani and H. Takata: J. Nucl. Mater. 69 \& 70(1978) 277. 